\title{
Seasonality in tuberculosis occurrence in the Federal District, Brazil
}

Leidijany Costa Paz ( $\nabla$ leidipaz@gmail.com )

Universidade de Brasilia https://orcid.org/0000-0002-5817-3444

Silvano Barbosa oliveira

Universidade de Brasilia Faculdade de Ciencias da Saude

Fernanda Monteiro de Castro Fernandes

Universidade de Brasilia

Antonio Felipe Couto Júnior

Universidade de Brasilia

Maria do Socorro Nantua Evangelista

Universidade de Brasilia Faculdade de Ciencias da Saude

Research article

Keywords: Tuberculosis, Seasonality, Climate, Time series analysis

Posted Date: February 17th, 2020

DOI: https://doi.org/10.21203/rs.2.23682/v1

License: (c) (1) This work is licensed under a Creative Commons Attribution 4.0 International License.

Read Full License 
TITLE: Seasonality in tuberculosis occurrence in the Federal District, Brazil

Authors' names:

\begin{tabular}{|c|c|c|c|}
\hline Authors & Affiliations & e-mail & ORCID \\
\hline $\begin{array}{l}\text { 1. Leidijany } \\
\text { Costa Paz }\end{array}$ & $\begin{array}{l}\text { University of } \begin{array}{r}\text { Brasilia, } \\
\text { Nursing } \\
\text { Graduate } \\
\text { Program, Brasilia, DF, } \\
\text { Brazil }\end{array} \\
\end{array}$ & $\begin{array}{l}\text { leidipaz@gmail.co } \\
\text { m }\end{array}$ & $\begin{array}{l}0000-0002- \\
5817-3444\end{array}$ \\
\hline $\begin{array}{l}2 . \quad \text { Silvano } \\
\text { Barbosa Oliveira }\end{array}$ & $\begin{array}{lr}\text { Ministry of Health, } \\
\text { Department } \\
\text { Immunization of } \\
\text { Communicable Diseases. }\end{array}$ & $\begin{array}{l}\text { silbaroli@yahoo.co } \\
\text { m.br }\end{array}$ & $\begin{array}{l}0000-0002- \\
1966-6115\end{array}$ \\
\hline $\begin{array}{l}\text { 3. Fernanda } \\
\text { Monteiro de Castro } \\
\text { Fernandes }\end{array}$ & $\begin{array}{l}\text { University of Brasilia, } \\
\text { Nursing } \\
\text { Program, Brasilia, DF, } \\
\text { Brazil }\end{array}$ & $\begin{array}{l}\text { fcastrojuju@gmail. } \\
\text { com }\end{array}$ & $\begin{array}{l}\text { 0000-001- } \\
9071-6034\end{array}$ \\
\hline $\begin{array}{l}\text { 4. Antônio } \\
\text { Felipe Couto Júnior }\end{array}$ & $\begin{array}{l}\text { University of Brasilia, } \\
\text { Graduate Program in } \\
\text { Environmental Sciences, } \\
\text { University of Brasilia, } \\
\text { Brasilia, Brazil. }\end{array}$ & afcj@unb.br & $\begin{array}{l}0000-0003- \\
3805-0540\end{array}$ \\
\hline $\begin{array}{l}5 . \quad \text { Maria do } \\
\text { Socorro Nantua } \\
\text { Evangelista }\end{array}$ & $\begin{array}{l}\text { University of Brasilia, } \\
\text { Nursing } \\
\text { Program, Brasilia, DF, } \\
\text { Brazil }\end{array}$ & socorrok@unb.br & $\begin{array}{l}\text { 0000-0002- } \\
4074-6101\end{array}$ \\
\hline
\end{tabular}

Address for the corresponding author:

Leidijany Costa Paz -

University of Brasilia

Nursing Graduate Program.

Darcy Ribeiro University Campus, Asa Norte. Brasília-DF. CEP: 70910-900.

55-61-3107-1753

leidipaz@gmail.com 


\begin{abstract}
BACKGROUND: Although tuberculosis (TB) is an endemic infectious disease in Brazil, the Federal District has a different epidemiology from other Brazilian locations. Investigation of disease seasonality, which needs to be further explored in tropical regions, may indicate risk factors specific to peak incidence seasons that could be controlled if better understood. To investigate the influence of seasonality (SA) in the occurrence of tuberculosis in the Federal District (FD) of Brazil. METHODS: This is an ecological time series (TS) study based on secondary data. The unit of analysis was the month of TB diagnosis from 2001 to 2018. We used the X-13ARIMA-SEATS (X-13) seasonal adjustment software in automatic mode with additive decomposition. Seasonality was analyzed using the Friedman test (0.001) and Kruskal-Wallis test (0.01) for stable seasonality. Moving seasonality was verified by Friedman test (0.05), and the identifiable seasonality was constructed from the combination of the three tests. The annual average seasonal amplitude was calculated from the isolated seasonal factors. RESULTS: 6,161 TB cases were diagnosed in the Federal District, 28 cases per month on average $( \pm 6.6)$. We observed peaks in April and August and decreased detection in November and December, with an average annual seasonal amplitude of $34.0 \%$. The F test and the Kruskal-Wallis test revealed evidence of SA at 0.001 and 0.01 , respectively. Moving SA was not identified at a significance level of 0.5 neither in the combination of the three tests. CONCLUSION: The TS tends to suggest a limited seasonality of TB in the FD. Some incidence peaks were observed in some specific months, showing a relevance of seasonality at the local level, which may reflect an influence of access to health service patterns from the onset of symptoms to the diagnostic elucidation of the disease.
\end{abstract}

Keywords: Tuberculosis; Seasonality; Climate; Time series analysis 


\section{BACKGROUND}

Tuberculosis (TB) is a high magnitude disease characterized by airborne transmission that is influenced by social, demographic, and genetic factors, as well as factors linked to immunosuppression, comorbidities, and access to health services (1-3). Although not yet completely elucidated, climatic and environmental factors (such as temperature, humidity, rain, sunlight, altitude, pollution, and seasonality) have been associated with the occurrence of the disease (4-6).

Since 1930, the phenomenon of seasonal variation in TB has been investigated (6) revealing a possible association of pathophysiological characteristics of the disease with the host, making the relationship between $\mathrm{TB}$ and seasonality complex (7). The international literature, however, reveals gaps in the relationship between seasonality and TB by region, as only a few studies have been conducted in locations that do not experience pronounced climate change throughout the year, or in areas close to the equator $(6,8)$. In this sense, the data reported in most studies refer to the northern hemisphere, above the Tropic of Cancer $(6,7)$, which makes it difficult to understand the association of climate determinants in the southern hemisphere with seasonal variations in the burden of disease. Considering the northern region, the literature has reported more pronounced TB-related seasonal peaks in spring and summer $(6,7,9)$.

The Federal District of Brazil (FD), where the capital of the country is located, has a different epidemiological scenario of tuberculosis compared with state capitals of the country (10). While Brazil ranks the $18^{\text {th }}$ position in TB burden and reports $33.0 \%$ of cases in the Americas (3), the capital city of the country has the lowest TB burden and, since 2008, reports an incidence very close to the WHO End TB strategy (3), which means, an incidence less than or equal to $10 / 100,000$ population(10). Despite efforts, studies on the epidemiology of local TB still seek to identify factors that may explain this phenomenon (10-12). One of the aspects to be analyzed would be how the seasonality of TB occurrence results in oscillatory movements of the same periodicity in the occurrence of events, in an intra-annual cycle (13). We believe that the present study can help in the creation of strategies that may contribute to the elimination of TB in the Federal District, meeting the objective of the End TB Plan in the country. Our study aims to investigate the seasonality in the occurrence of tuberculosis in the Federal District-Brazil from 2001 to 2018. 


\section{2 - METHODS}

The present study was conducted in the Federal District (FD), a federated unit that houses the capital of Brazil. The region is positioned at the parallels $15^{\circ} 30^{\prime}$ and $16^{\circ} 03^{\prime}$ south latitude and the meridians $47^{\circ} 25^{\prime}$ and $48^{\circ} 12^{\prime}$ west longitude in the Midwest, lying in the central region of Brazil and in the East Center of the state of Goiás. The FD has an area of 5,783 square $\mathrm{km}$ and represents $0.06 \%$ of the area of the national territory. As for the topography, the altitudes vary from $950 \mathrm{~m}$ to $1400 \mathrm{~m}$, with a predominance of relief characterized by erosional evolution formed by plateaus and tablelands. The country has a tropical climate with two well-defined seasons: hot and rainy (spring-summer) and cold and dry (autumn-winter). The average temperature recorded over the last 30 years was $22^{\circ} \mathrm{C}$, ranging from $13^{\circ} \mathrm{C}$ to $28^{\circ} \mathrm{C}$ throughout the year. The average annual rainfall was 1,400 mm (14). In 2018, the population estimate of the Federal District was 2,974,703 inhabitants and the average population density was 410.8 inhabitants/sq. km, with an urbanization rate of $94,7 \%(15)$.

We conducted an ecological time series study based on secondary data. We used the classification "case" of tuberculosis, as recommended by the Brazilian National TB Control Program of the Ministry of Health (16). We analyzed all new TB cases (pulmonary, extrapulmonary, and pulmonary + extrapulmonary) reported to the National System of Notification of Disorders (Sistema Nacional de Agravos de Notificação SINAN) diagnosed between January 2001 and December 2018, totaling 6,161 TB cases. The data are available electronically on the website of the data-processing Department of the Unified Health System at http://www2.datasus.gov.br/DATASUS/index.php?area=0203\&id=31009407\&VObj=ht tp:/ /tabnet.datasus.gov.br/cgi/tabcgi.exe?sinannet/cnv/tuberc. The absence of ethical appraisal is justified by the fact that the data is available from official open access banks.

\section{1 - STATISTICAL ANALYSIS}

To compile the historical series of $\mathrm{TB}$ cases we used descriptive statistics of frequency, proportion, mean, median, mode, and standard deviation (minimum and maximum). We included all cases, regardless of clinical presentation, skin color/race, education, and gender. We excluded 868 cases of relapse, change of diagnosis, readmission after treatment withdrawals, and transfers. In the seasonality analysis, the annual records of TB in the Federal District were disaggregated by month of diagnosis, 
totaling a time series of 216 observations (18 years). In our study, the month TB was diagnosed was defined as "unit of analysis."

To evaluate the seasonality of TB in the FD, we used the X-13ARIMA-SEATS (X-13) seasonal adjustment software, made available by the US Census Bureau in July 2012 (17) and implemented in the R-interface version 3.6.0. We set X-13ARIMA-SEATS in automatic mode, which revealed the need for log-transformation of the data: presence of outliers; the order of the ARIMA (Autoregressive Integrated Moving Average) model; and the existence of calendar effects (trading days, working days, holidays) $(13,18)$.

Running the X-13ARIMA-SEATS in automatic mode, we compared the transformed series and the post transformation series using log likelihood function (L), Akaike Information Criterion (AIC), Finite Sample AIC (FAIC), Hannan Quinn Information Criterion (HQC), and Bayesian Information Criterion (BIC) for model adequacy. After the adaptation of the five best ARIMA models used in this series, we observed no need for transformation of the original series and no unit root was found. The final model identified was the ARIMA $(0,1,1)$.

To estimate the seasonal component $\left(S_{n}\right)$ the series was decomposed by the additive model $\left(\mathrm{X}_{n}=\mathrm{T}_{n}+\mathrm{S}_{n}+\mathrm{I}_{n}\right)$, isolating this component from the general trend $\left(\mathrm{T}_{\mathrm{n}}\right)$ and the irregular components $\left(\mathrm{I}_{n}\right)$, where $X_{n}$ is the number of observed TB cases in the Federal District in the month $=n(13)$. The presence of seasonality was analyzed using the Friedman test (significance level set to less than 0.001) and the Kruskal-Wallis test (significance level set to less than 0.01), in order to assess the presence of stable seasonality. The moving seasonality was verified by Friedman test (significance less than 0.05), besides the identifiable seasonality, constructed from the combination of the three tests: identifiable seasonality not present, identifiable seasonality probably not present, and identifiable seasonality present (Appendix 01).

The annual average seasonal amplitude was calculated from the isolated seasonal factors and defined as the fraction where the numerator was established by the difference between the months with the highest and lowest TB case count in the period, and the denominator was the average number of cases in the studied period. Thus, a proportion of the average annual case count was obtained. 


\section{3 - RESULTS}

From January 2001 to December 2018, 6,161 TB cases were diagnosed in the Federal District. On average, 28 cases of TB $( \pm 6.6)$ per month were notified, with a median of 29 cases, mode of 24 people, minimum of 11, and maximum of 47 people diagnosed per month. The highest rates of TB cases were among men (3,931 people, $63.8 \%)$, age group $20-39$ years $(3,931,43.2 \%)$, blacks $(3,434,55.7 \%)$, pulmonary clinical presentation $(4,609,74,8 \%)$, cases of positive sputum smear microscopy $(2,546,41,3 \%)$, and negative HIV tests $(3,172,51,5 \%)$. More than $51 \%$ of TB cases in the FD $(n=3,173)$ were laboratory-confirmed during the study period (Table 1).

Figure 2 shows the decomposed time series (TS). In the first window the original TS showed the number of TB cases observed monthly in the Federal District; the second one showed the trend of TB over time, pointing to a non-uniform oscillation of TB case reporting, especially with evidence at two moments of a significant drop in case detection, corresponding to the period 2008-2012, as well as the year 2017. In turn, the third window, referring to the seasonal component, revealed oscillatory movements at the same intra-annual periodicity and repetitive movements throughout the historical series. This feature, both in the seasonal component (Figure 01) and in the corresponding seasonal adjustment factors (Table 2), revealed that the months of April and August presented an increasing number of TB cases, as well as a lower notification rate in November and December, in all 18 years analyzed.

The irregular component or fourth window (Figure 1) showed all the effects that were not incorporated by the TS via the three previously mentioned components, that is, we observed a random variation, also called white noise.

Considering Figure 2, we observed that the mean and variance found were not constant in this TS. However, there was a higher median and mean TB detection rate in August (33.5 and 33.6; respectively), as well as lower variability in the number of cases, also in August. On the other hand, November and December had a lower occurrence of cases and revealed greater variations in TB over 18 years. The average annual seasonal amplitude observed was $34.0 \%$, with a seasonally adjusted variation from -7 to +6 cases (Table 2).

Regarding the stability of TB cases over time, we identified that seasonality was present at a significance level of 0.001 (Table 3.A). In addition, there was evidence of seasonality for people with TB at the 0.01 level (Table 3.B). However, seasonality was not identified when associated with moving TB, with a significance level of 0.5 (Table 
3.C). Finally, the combination of the three tests found no association between seasonality and TB in the Federal District (Table 3).

\section{4 - DISCUSSION}

Brazil is part of the WHO's list of high TB burden countries, both based on the number of TB cases and on the association between TB and HIV. In 2018, while the country had an incidence of 33.5 cases per 100,000 population, the Federal District reported an incidence of $11.5 / 100,000$ population, being the second capital with the lowest TB incidence rate in the country and the lowest in the Midwest region. That is, this incidence is very close to the WHO End TB strategy $(3,10)$, which is 10 cases/100,000 population. Considering this disparate scenario of a country with a high TB burden, the distribution of cases between sex, age, race/color, and clinical presentation is similar to regional and national findings. Regarding the results and quality indicators of the tuberculosis program, laboratory confirmation of TB cases in the FD remained around $50.0 \%$ of the cases in the analyzed series, which may be justified by gaps in access to diagnostic tools, as well as difficulties inherent in the pathophysiology of the disease itself $(10,19)$.

Seasonality of TB has been reported worldwide and is considered consistent in view of the different TB disease burden(6). Seasonality of TB was identified in the northern hemisphere with reports of TB notification peaks in the months of March to August (spring/summer) and fall in disease notification between October and February (autumn/winter). In the southern hemisphere, seasonal patterns reported revealed a higher occurrence of TB cases between August and December (winter/spring), and the lowest detection of cases from March to July (autumn/winter) (6,7). Although the seasonality of TB has been reported in many studies, the results fail to show a similar distribution worldwide $(6,7)$. This insufficiency becomes more relevant in regions close to the equator, where annual seasons are not well defined, and, therefore, evidence of TB seasonality has been contradictory $(6,7,20,21)$. In this series, the months of April and August revealed a growing number of new TB cases, as well as lower notification in November and December. Probably, this drop in the identification of TB cases reflects much more gaps in the implementation of health promotion initiatives than a decrease in infectious agent circulation in the Federal District.

In the 18-year historical series of epidemiological surveillance of TB, peaks in the diagnosis were observed in April and August, with a more pronounced decrease in case detection in November and December, with an average annual seasonal amplitude of 
$34.0 \%$. This amplitude is very close to that found in the US with $33.6 \%$ (22) and the Netherlands - 29.2\% (23). Tedjano et al. (2018) calculated the standardized seasonal amplitude from 34 studies in a systematic review and identified an average of $17.1 \%$ (variation: 2.7-85.5\%) after weighing the sample size of each study.

A quarterly analysis of the period 2003/2012 in the Federal District revealed a higher occurrence of tuberculosis in winter (11). The present study, with a larger historical series and monthly disaggregation level, also identified winter seasonality from decomposition with X-13. Assuming seasonality stability, the F-test was significant at the level of $0.1 \%$, and the Kruskal-Wallis test had evidence of seasonality at the level of $1 \%$. However, the test for seasonality in motion was not significant at the 5\% level, as well as after the combination of the tests employed. It is noteworthy that the model used here verified calendar effects (leap year, Easter, and working days).

The Federal District is located in an intertropical area where previous studies also failed to reveal a strong seasonal pattern $(20,21)$. However, it is noteworthy that studies in this region are still scarce and reveal contradictions. However, in Australia and India, which are closer to the equator, studies have not shown TB presence considering seasonality $(24,25)$. Moreover, in the United States, no difference in seasonality was identified when data were stratified by latitude $(6,26)$.

Such findings may be anchored in the condition that the Federal District shows less variability in human agglomeration, as well as relative stability in climate and solar radiation levels. The climate of the Federal District is tropical with dry season (Aw Köppen-Geiger climate), monthly average temperatures above $22^{\circ} \mathrm{C}$, and average annual rainfall of 1,400 mm, concentrated between October and April. During the dry season (May to September), the relative humidity levels may decrease to below 30.0\%. Although the FD does not record very low monthly temperature averages, from June to mid-August the population faces significant thermal change, particularly with cold nights and intense heat during the day, and, at the height of the afternoon, humidity can fall below $17.0 \%$ $(14,27)$.

It is noteworthy that very low humidity levels in the dry season affect the respiratory mucosae, increasing the susceptibility to the manifestation of acute respiratory infections (28). The consequences of acute respiratory viral infections in individuals infected with Koch's bacillus have not been well studied so far. However, reports indicate a negative influence of influenza A infection before or during Mycobacterium tuberculosis infection, significantly increasing the susceptibility of hosts to TB disease 
(29-31). In turn, this increased demand for health services due to respiratory disorders may be driving the peak of diagnosis in August in the Federal District, as respiratory symptomatic persons are part of the TB screening protocol.

When interpreting the results in this series, some limitations may be pointed out. Firstly, we used official data with secondary databases, noting that this is a source of data from the Brazilian Ministry of Health on tuberculosis, which is subject to underreporting. Secondly, while the X-13ARIMA-SEATS approach is recommended for seasonal time series adjustment and we have set the calendar to automatic mode (Easter, leap year, and working days), Brazilian Carnival and Corpus Christi holidays were not included. Finally, in the present study, the seasonality of TB incidence was not stratified according to age, HIV infection, clinical presentation, and laboratory confirmation. Therefore, the expansion this study is recommended to explore these variables.

We would like to highlight that the decrease in the detection of cases in the months November to December in the FD may reflect the reduction of the behavior of the population seeking health services, particularly by the reduction of access, that is, the low availability of health services during holiday season, reinforcing the importance of further investigation into the mechanism(s) involving tuberculosis seasonality in the Federal District.

\section{5 - CONCLUSIONS}

The present study suggests a limited seasonality of tuberculosis in the Federal District - Brazil. However, some incidence peaks were observed, specifically in some months, showing a relevance of seasonality at the local level, reflected in the access patterns and the time taken from symptom onset to the diagnostic elucidation of the disease. Thus, the seasonality component provides useful information to the decisionmaking process, as seasonal factors are relevant for short- and medium-term planning, as well as for the operationalization of TB control strategies. At the same time, it allows managers a more accurate surveillance of cases considering such months. 


\section{LIST OF ABBREVIATIONS:}

FD - Federal District

WHO - World Health Organization

SINAN - National System of Notification of Disorders

DATASUS - Department of the Unified Health System

L - Likelihood function

AIC - Akaike Information Criterion

FAIC - Finite Sample AIC

HQC - Hannan Quinn Information Criterion

BIC - Bayesian Information Criterion

ARIMA - Autoregressive Integrated Moving Average

S - Seasonal

$\mathrm{T}$ - Trend

I - Irregular

SEATS - Signal Extraction in ARIMA Time Series 


\section{DECLARATIONS}

\section{1 - Ethics approval and consent to participate}

The data are available electronically on the website of the data-processing Department of the Unified Health System (DATASUS) at http://www2.datasus.gov.br/DATASUS/index.php?area=0203\&id=31009407\&VObj=ht tp://tabnet.datasus.gov.br/cgi/tabcgi.exe?sinannet/cnv/tuberc.

The absence of ethical appraisal is justified by the fact that the data is available from official open access banks (Resolution No. 510, of April 7, 2016/ Ministry of Health of Brazil).

\section{2 - Consent for publication}

Not applicable

\section{3 - Availability of data and materials}

The datasets analysed during the current study are available in the Department of the Unified Health System (DATASUS) at http://www2.datasus.gov.br/DATASUS/index.php?area=0203\&id=31009407\&VObj=ht tp://tabnet.datasus.gov.br/cgi/tabcgi.exe?sinannet/cnv/tuberc.

\section{4 - Competing interests}

The authors declare that they have no competing interests.

\section{5 - Funding}

The present study did not receive external funding.

\section{6 - Authors' contributions}

LCP contributed to the study conception, implementation of the study, design, interpretation, critical and drafting of the manuscript. SBO contributed to design and data analysis. FMCF was involved in drafting and revising the manuscript. AFCJ interpretation of data and was involved in drafting and revising the manuscript and MSNE contributed to the conception and design of data,riting - original draft and revising the manuscript. All authors read and approved the final manuscript.

\section{7 - Acknowledgements}

Not applicable

\section{8 - Authors' information (optional)}

Not applicable 


\section{6 - REFERENCES}

1. Balcells ME, García P, Tiznado C, Villarroel L, Scioscia N, Carvajal C, et al. Association of vitamin D deficiency, season of the year, and latent tuberculosis infection among household contacts. PLoS One [Internet]. 2017 [cited 2019 Oct 18];12(4):e0175400. Available from: http://www.ncbi.nlm.nih.gov/pubmed/28403225

2. Sales CMM, Nunes GF, Rogério W, Castro T, Santos BR, Maciel ELN. Tuberculose e a questão social: uma revisão sistemática de estudos brasileiros. Rev Bras Pesqui em Saúde/Brazilian J Heal Res. 2016 Nov 4;17(4):156-75.

3. World Health Organization 2018. GLOBAL TUBERCULOSIS REPORT 2018 [Internet]. 1st ed. World Health Organization., editor. Geneva; 2018 [cited 2019 Oct 18]. 297 p. Available from: http://apps.who.int/bookorders.

4. Soetens LC, Boshuizen HC, Korthals Altes H. Contribution of Seasonality in Transmission of Mycobacterium tuberculosis to Seasonality in Tuberculosis Disease: A Simulation Study. Am J Epidemiol [Internet]. 2013 Oct 15 [cited 2019 Aug 21];178(8):1281-8. Available from: https://academic.oup.com/aje/article-lookup/doi/10.1093/aje/kwt114

5. Wingfield T, Schumacher SG, Sandhu G, Tovar MA, Zevallos K, Baldwin MR, et al. The seasonality of tuberculosis, sunlight, vitamin D, and household crowding. J Infect Dis [Internet]. 2014 Sep 1 [cited 2019 Aug 20];210(5):774-83. Available from: http://www.ncbi.nlm.nih.gov/pubmed/24596279

6. Tedijanto C, Hermans S, Cobelens F, Wood R, Andrews JR. Drivers of seasonal variation in tuberculosis incidence: Insights from a systematic review and mathematical model. Vol. 29, Epidemiology. Lippincott Williams and Wilkins; 2018. p. 857-66.

7. Santos LG, Pires GN, Azeredo Bittencourt LR, Tufik S, Andersen ML. Chronobiology: Relevance for tuberculosis. Tuberculosis. 2012 Jul;92(4):293300.

8. Ballif M, Zürcher K, Reid SE, Boulle A, Fox MP, Prozesky HW, et al. Seasonal variations in tuberculosis diagnosis among HIV-positive individuals in Southern Africa: Analysis of cohort studies at antiretroviral treatment programmes. BMJ 
Open. 2018 Jan 1;8(1).

9. Fares A. Seasonality of tuberculosis. J Glob Infect Dis. 3(1):46-55.

10. Brasil.Ministério da Saúde. Secretaria de Vigilância em Saúde. Boletim Epidemiológico. Brasil Livre da Tuberculose: evolução dos cenários epidemiológicos e operacionais da doença. [Internet]. Brasília; 2019 [cited 2019 Aug 21]. Available from:

http://portalarquivos2.saude.gov.br/images/pdf/2019/marco/22/2019-009.pdf

11. Fernandes FM de C, Martins E de S, Pedrosa DMAS, Evangelista M do SN. Relationship between climatic factors and air quality with tuberculosis in the Federal District, Brazil, 2003-2012. Brazilian J Infect Dis. 2017;21(4):369-75.

12. RODRIGUES OMMR. Aspectos clínicos e epidemiológicos da tuberculose no Distrito Federal (2006 a 2015). Universidade de Brasília; 2017.

13. Ferreira PGC, Barros AC, Mattos DM, Oliveira ICL, Duca VELA. Análise de séries temporais em R: curso introdutório. 1ª . FGV IBRE, editor. Rio de Janeiro; 2018. 264 p.

14. CODEPLAN. ATLAS DO DISTRITO FEDERAL 2017. BRASILIA; 2017.

15. IBGE. Cidades Brasileiras [Internet]. 2019 [cited 2019 Aug 21]. Available from: https://cidades.ibge.gov.br/

16. Brasil. Ministério da Saúde. Secretaria de Vigilância em Saúde. Departamento de Vigilância das Doenças Transmissíveis. MANUAL DE RECOMENDAÇÕES PARA O CONTROLE DA TUBERCULOSE NO BRASIL. [Internet]. Ministério da Saúde, editor. BRASILIA; 2019 [cited 2019 Aug 21]. Available from: www.saude.gov.br/

17. USA USCB. X-13ARIMA-SEATS Seasonal Adjustment Program. 2012.

18. Sax C, Eddelbuettel D. Seasonal Adjustment by X-13ARIMA-SEATS in R [Internet]. [cited 2019 Oct 18]. Available from: http://www.seasonal.website

19. VERONESI R, FOCACCIA R. Tratado de Infectologia. $5^{\mathrm{a}}$. Atheneu, editor. 2015. 2600 p.

20. Jaganath D, Wobudeya E, Sekadde MP, Nsangi B, Haq H, Cattamanchi A. 
Seasonality of childhood tuberculosis cases in Kampala, Uganda, 2010-2015.

Shaman J, editor. PLoS One [Internet]. 2019 Apr 9 [cited 2019 Aug

18];14(4):e0214555. Available from:

http://dx.plos.org/10.1371/journal.pone.0214555

21. Wah W, Das S, Earnest A, Lim LKY, Chee CBE, Cook AR, et al. Time series analysis of demographic and temporal trends of tuberculosis in Singapore. BMC Public Health [Internet]. 2014 Dec 31 [cited 2019 Aug 18];14(1):1121. Available from: http://bmcpublichealth.biomedcentral.com/articles/10.1186/1471-2458-141121

22. Mao Q, Zhang K, Yan W, Cheng C. Forecasting the incidence of tuberculosis in China using the seasonal auto-regressive integrated moving average (SARIMA) model. J Infect Public Health. 2018;11(5):707-12.

23. Korthals Altes H, Kremer K, Erkens C, van Soolingen D, Wallinga J. Tuberculosis seasonality in the Netherlands differs between natives and nonnatives: a role for vitamin D deficiency? Int J Tuberc Lung Dis [Internet]. 2012 May [cited 2019 Oct 18];16(5):639-44. Available from: http://www.ncbi.nlm.nih.gov/pubmed/22410705

24. Narula P, Sihota P, Azad S, Lio P. Analyzing seasonality of tuberculosis across Indian states and union territories. J Epidemiol Glob Health [Internet]. 2015 Dec 1 [cited 2019 Aug 18];5(4):337-46. Available from:

https://www.sciencedirect.com/science/article/pii/S2210600615000313

25. Maclachlan JH, Lavender CJ, Cowie BC. Effect of latitude on seasonality of tuberculosis, Australia, 2002-2011. Emerg Infect Dis [Internet]. 2012 Nov [cited 2019 Aug 18];18(11):1879-81. Available from:

http://www.ncbi.nlm.nih.gov/pubmed/23092594

26. Chen MP, Shang N, Winston CA, Becerra JE. A Bayesian analysis of the 2009 decline in tuberculosis morbidity in the UnitedStates. Stat Med. 2012 Nov 30;31(27):3278-84.

27. Neves GZF, Specian V, Rocha T, Vecchia FA da S. SÍNTESE DOS ESTUDOS CLIMÁTICOS E A DISTRIBUIÇÃO DA REDE METEOROLÓGICA NO ESTADO DE GOIÁS E DISTRITO FEDERAL. In: UNICAMP, editor. XVII 
Simpósio Brasileiro de Geografia Fpisica Aplicada [Internet]. Campinas - SP; 2017. p. 12. Available from: http://ocs.ige.unicamp.br/ojs/sbgfa/article/view/2583

28. Mendy J, Jarju S, Heslop R, Bojang AL, Kampmann B, Sutherland JS. Changes in Mycobacterium tuberculosis-specific immunity with influenza co-infection at time of TB diagnosis. Front Immunol. 2019;10(JAN).

29. Ring S, Eggers L, Behrends J, Wutkowski A, Schwudke D, Kröger A, et al. Blocking IL-10 receptor signaling ameliorates Mycobacterium tuberculosis infection during influenza-induced exacerbation. JCI Insight. 2019 May 16;4(10).

30. Redford PS, Mayer-Barber KD, McNab FW, Stavropoulos E, Wack A, Sher A, et al. Influenza A virus impairs control of mycobacterium tuberculosis coinfection through a type i interferon receptor-dependent pathway. J Infect Dis. 2014 Jan $15 ; 209(2): 270-4$.

31. Flórido M, Grima MA, Gillis CM, Xia Y, Turner SJ, Triccas JA, et al. Influenza A virus infection impairs mycobacteria-specific $\mathrm{T}$ cell responses and mycobacterial clearance in the lung during pulmonary coinfection. J Immunol [Internet]. 2013 Jul 1 [cited 2019 Oct 18];191(1):302-11. Available from: http://www.ncbi.nlm.nih.gov/pubmed/23698750 
Figures

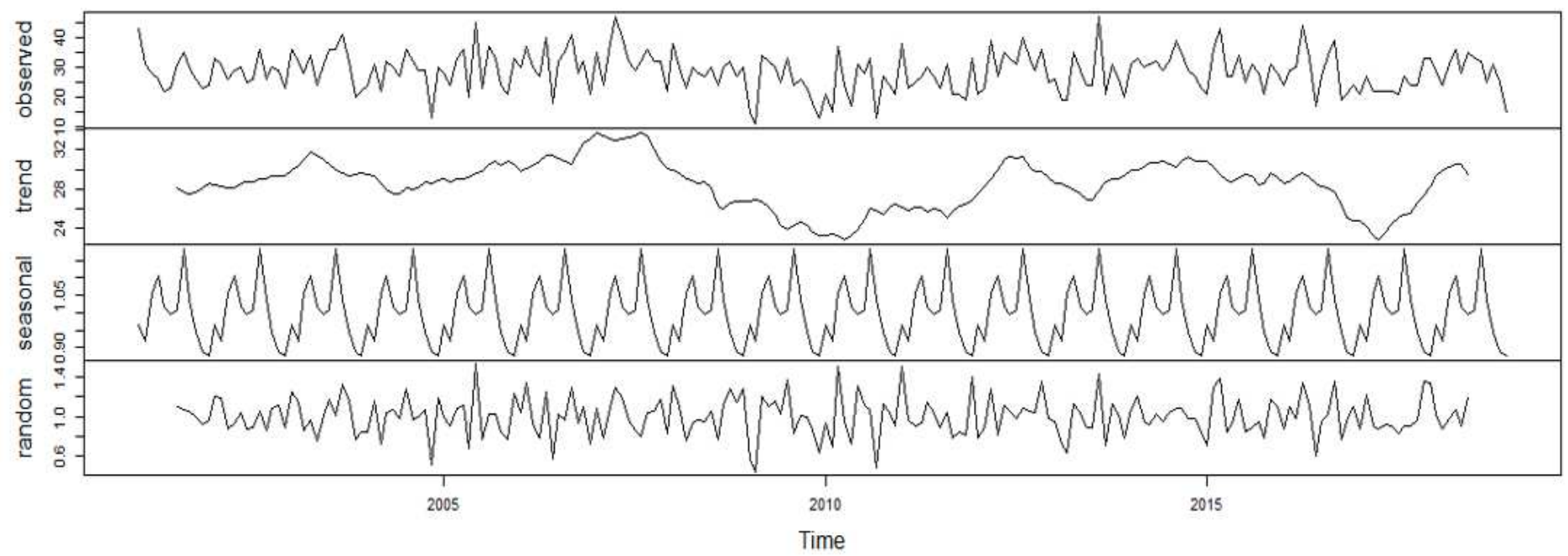

Figure 1

Additive decomposition of the monthly time series of TB cases in the Federal District, Brazil (2001-2018)

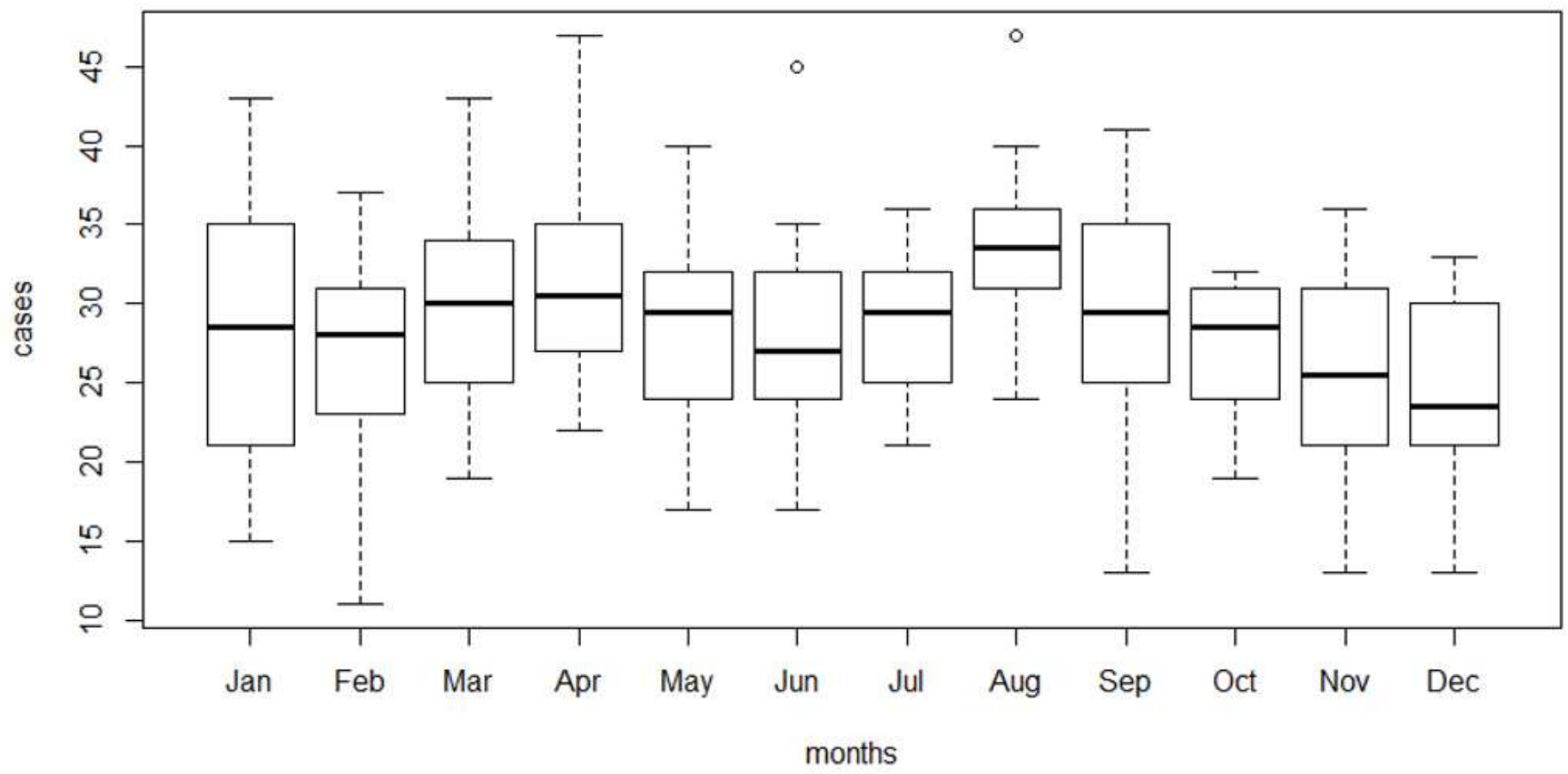

Figure 2

Box-plot of monthly distribution of tuberculosis cases. Federal District, Brazil, (2001 - 2018)

Supplementary Files 
This is a list of supplementary files associated with this preprint. Click to download.

- figuraseapendice.pdf 